\title{
Challenges of Albania towards the European Integration
}

\section{Ermelinda Shehaj}

\author{
PhD Candidate, University of Tirana, Institute of European Studies
} ermelindashehaj@yahoo.com

\section{Doi:10.5901/mjss.2015.v6n4s2p571}

\begin{abstract}
This paper examines the role of European Union has in developing a real democracy. At present, our country faces various challenges while it aligns itself in the road of democratization and in European integration. In my opinion, the most important three are: 1-The need for a well-rounded and good intending political and administrative elite. 2-The need for truly independent government branches as described in the constitution. 3-The need for an independent civic society. The main objectives of this study are to: Define the concept of the Albanian democracy; to identify the key factors affecting the lack of democracy. This paper tries to discuss the present problems and challenges towards the process of democratization and European integration too. At the last is to propose possible strategic approach for democracy to develop the whole society towards the European Integration. The paper is based on different theories related to democracy and political parties. This paper analyzes the relation between Albania and European Union is progressing during the transition period, try to give an overview between their relation these years and takes into consideration the impact of others actors in society in building a real democracy such as are: cultural factors, political parties, civil society and especially the relation between the citizens and representatives of a state (political parties).
\end{abstract}

Keywords: democracy, political parties, civic society, independent institutions, democratic values, European integration

\section{Introduction}

Albania has been trying to successfully conclude the process of democratization, European integration ever since the collapse of the communist regime. A democratic system is a system that is build and runs based on a necessary set of values, which complement and need each other such as: justice, freedom, security, prosperity; as well as the clean build of a fully functioning democratic system with prevailing democratic values, balanced and independent governmental branches. Equally important, a strong, capable and true to itself civic society adds sturdiness to the fabric of democracy. At present, our country faces various challenges while it aligns itself in the road in European integration. In my opinion, the most important three are:

1. The need for well-rounded and good intending political and administrative elite.

2. The need for truly independent government branches as described in the constitution.

3. The need for an independent civic society.

Due to its isolating past, Albanian society has been suffering for unconditional tolerance and respect of basic democratic values. The absence of tolerance can be seen daily in our lives and it beams down from our politicians to the common people. Albanian society has been suffering for unconditional tolerance and respect of basic democratic values. The absence of tolerance can be seen daily in our lives and it beams down from our politicians to the common people. There are other challenges worthy of mentioning but, I believe that the three stated above are the most important ones. In conclusion, the road that leads to a sound democracy and European Integration is a very hard and complicate road. The integration process cannot be successful without the constructive involvement of all actors in our society. A democratic system can't be successful without democratic parties, political elites equipped with democratic culture, without independent institutions and a self-conscious civic society who takes part and reacts to cultural and system shaping phenomena. Democracy is not means but our common desired end. Democratic values can't be separated from the European countries. Member states of EU need to do a lot to protect the democratic values. It is necessary to create a safe environment for protecting the human rights, free and fair election, freedom and all values related to a democratic system. In this paper I will analyze my country, Albania which is the challenges of democratization towards the European Union

Unfortunately, tolerance to different ideas, thoughts, behaviors, political stands and morals has been low. Beneath the continuous freshly painted cosmetics, the issue of intolerance remains the same. Due to past and present examples, 
many believe that tolerance will remain simply and ideal for many other years to come. This negative element of our society is continuously supported by examples by our politicians who seem to be unable to put a limit to their political wars. Quite often, the Albanian politics has served as a catalyst for the constant moral deformation of our society by valuing and nurturing uncontrolled militantism. The final intent of this model, followed largely by most politicians, can be easily described in Sartre's words: "Political parties can only be means to achieve the final intent, power. It seems that this chase for power and the misuse of the political parties for this purpose has put to danger the true mission of political parties in democratic societies: the concentration of knowledge and political will that opens the road for continuous dialog between the government and the people. Albanian politics not only does not work towards producing an ever needed message of tolerance; it persists on being polarized and divided on various issues and at war with itself while continuously producing individual accusations and lacking clear vision for the future. Albanian politics needs change. It needs to change the way it thinks and acts as a whole. It needs to be more accepting intra party democracy and change. The lack of new ideas and clear vision are now transparent to most Albanians.

In our country, politics shape shifts continuously from grotesque art to unethical business and electoral traffic. It incorporates all those negative elements, lies, manipulation and hypocrisy among many others, which impede democracy to prosper as the people idealize it. The abuse of the system for personal profits shows that most politicians have forgotten that they as the rest of us are citizens with basic equal rights and responsibilities and that the vote is not a gift but a contract that requires them to fully serve democracy as the only way forward.

As mentioned above, the need for truly independent government branches as described in the constitution represents another challenge for the Albanian society and its will to European Integration. It has been seen that Albanian politician, after achieving power, focus their energies towards controlling all institutions and governments branches whose independence is assured in the constitution. There have been cases when various institutions have been by products of political will for absolute control and dominance hence they have never been independent. Routinely, newly elected parties and politicians start their attacks on independent institutions by changing the administration and injecting their militants which in many cases have been untrained or unqualified. This new wave of employed militants is easily commended and serves the individual interests of the political leaders; destroying the independence, those institutions might have from the executive branch. Under such a chaos, the branches of government not only have not fulfilled their constitutional duty of controlling each other's activities but also have fallen prey of personal vendettas and mediocre business interests. The inexistence of independent institutions threatens democracy itself and paves the way for negative phenomena such as despotism, disrespect for the law, absence of transparence etc. It is clear that independent institutions are a necessity for a democratic system. They protect the citizens and their rights from abuse; they pave the way for a sound, healthy and constructive opposition. The independent institutions are sacred as they belong to all the citizens, as they serve them based on the power given to them by the people themselves.

\section{An Overview of the Relations EU-Albania}

Albania has experienced large political, institutional and socio-economic shift in the last 25 years of democracy that followed half a century of dictatorship. The European dream, the desire to join the EU is at strong as it was when the democracy movement dismantled communism in the early 90s. The call of "Making Albania like Europe" has been translated into rational political objectives as European integration has become a priority reflected in the agenda of the main political parties and all government programmes. European integration Represent the highest priority in the policy agenda of the Government of Albania.

Albania is a potential candidate for the EU membership following the Thessaloniki European Council of June 2003. On 18 February 2008 the Council adopted a new European partnership with Albania. The Stabilization and Association Agreement (SAA) ${ }^{1}$ with the country was signed on 12 June 2006 and entered into force on 1 April 2009, while Albania received the NATO membership on 4 April 2009. It supersedes the Interim Agreement ${ }^{2}$ on trade and trade-related aspects, which entered into force in December 2006.

In January 2008, the visa facilitation agreement entered into force and for the period of March-June 2008, the European Commission launched the visa liberalization dialogue and presented a road map identifying specific

\footnotetext{
${ }^{1}$ Council of the European Union, Brussels, 22 May 2006, 8164/06, COWEB 76, Legislative Acts and other Instruments- Stabilization and Association Agreement between the European Communities and their Member States, on the one part and the Republic of Albania, on the other part.

2 Council of the European Union, Brussels, 22 May 2006, 8154/06, COWEB 73, Legislative Acts and other Instruments-Interim Agreement on Trade-related matters between the European Community, of the one part, and the Republic of Albania, on the other part. 
requirements for visa liberalization with Albania and negotiations on visa liberalization with EU are underway. The visa facilitation and readmission agreement ${ }^{3}$ between Albania and the European Community is being implemented. According to Albania 2009 Progress Report ${ }^{4}$, the visa liberalization dialogue has made good progress in the areas of justice, liberty and security, but has not yet met all the benchmarks set in the roadmap. Further efforts have been required with regard to the personalization and distribution of biometric passports, border and migration management and the institutional framework to fight organized crime and corruption.

Since 2007 the pre-accession financial assistance to Albania is provided under the instrument of Pre-Accession Assistance (IPA). The IPA 2009 agreement was signed on 9th March 2009; IPA 2009 planning process has been completed, while IPA 2010 will start in July 2009. The matter we can say is that the focus includes these areas: home affairs and justice, democratic stabilization, capacity for building an effective administration and social development.

The acquis translation process into Albania has started since 2007. Albania applied for the EU candidate status since on 28 April 2009. The Government of Albania has submitted the competed questionnaire with 2285 questions to the EU. Based on this and after the verification from the Commission, it will be seen if it is a positive advise (the Opinion) that the European Commission will prepare on Albania and that will be submitted to the Council of Ministers of the EU. If this will be the case Albania will receive the EU candidate status and will open the negotiations for the full membership into the EU. Taking into the consideration that this process might last up to one year and half depending on the internal development within Albania and the EU, then the political parties in the country should be careful to resolve the possible gaps where the EC might base its opinion.

\section{EU Integration Path}

The European Council in Feira in June 2000 confirmed the objective of the fullest possible integration of the countries of the Western Balkans ${ }^{5}$ into the political and economic mainstream of Europe and recognized these countries as potential candidate for achieving candidate status and after that being the member of the European Union.

In December 2002 this perspective was reaffirmed by Copenhagen European Council. It underlined the European Union's determination and will to continue to support them in their efforts for building real democracy and democratic political parties and effective institutions.. The Brussels European Council in March 2003 stated that "the future of the Western Balkans is within the EU" and invited "the Council and the Commission to examine the ways and means, based also on the experience of the enlargement process to further strengthen the Union's policy towards the region. 6 " We can say that an important priority of the European Union is integration of Western Balkans countries at the Union because they think that the Europe will not be complete until these countries will part of European Union. They belong to European Union for many reasons such as are: their positions into the region, but not only and the other characteristics of culture.

The Stabilization and Association process (SAP) is the EU's policy for relations between the Union and the Western Balkans countries. This process is very useful for Western Balkans countries because help the five countries to develop their reforms in different fields and then they are able to go closer to the European Union being member of it. This process is very important because it guarantees and promotes the stability in this region.

\footnotetext{
3 Since the entry into force Treaty of Amsterdam on 1 May 1999, Policy of Readmission was accelerated Art. 63(3) (b) EC establishes the authority of the Community to take "measures on immigration policy in the area of illegal immigration and illegal residence, including repatriation of illegal residents. Mandate was given by the Council to negotiate a readmission agreement between the European Community and Albania on 28 November 2002. Three negotiating round were held with the Albanian authorities between May and November 2003. The agreement was then initialed by the European Commission and a representative of the Government of Albania in Brussels on 18 December 2003. Following the initialing of the Agreement the COM officially submitted to the Council the final text together with two draft decisions concerning the signing and the conclusion of it (COM 200492 Final of February 2004). Due to European Elections and the considerable time needed to meet additional translation requirements following EU enlargement, the agreement is not expected to be formally concluded before mid-2005. On 2 March 2005, the Council approved the decision on the signing of the Agreement.

${ }^{4}$ Commission of the European Communities, Brussels, 14 October 2009, SEC (2009) 1337, Commission Staff working DocumentAlbania 2009 Progress Report accompanying the Communication from the Commission to the European Parliament and the Council "Enlargement Strategy and main Challenges for 2009-2010", COM (2009) 533

${ }^{5}$ The countries covered by the Stabilization and Association process, the EU's policy for the Western Balkans; are Albania, Bosnia and Herzegovina, Croatia the former Yugoslav Republic of Macedonia, Serbia, Montenegro and including Kosovo as defined in the UN security Council Resolution 1244/99.

${ }^{6}$ The countries covered by the Stabilization and Association process, the EU's policy for the Western Balkans; are Albania, Bosnia and Herzegovina, Croatia the former Yugoslav Republic of Macedonia, Serbia, Montenegro and including Kosovo as defined in the UN security Council Resolution 1244/99.
} 
The Treaty of the Athens in April 2003, which paves the way to the accession of ten new Member States, the Thessaloniki Summit provides the occasion to give a new impetus to the Stabilization and Association process ${ }^{7}$. Western Balkans has a good example for achieving EU membership from countries of Eastern Europe which really succeed in fulfillment the criteria of European Union. Now it is their turn to show the Europe that they will do the same, will be able to build a real democracy, to have an efficient administration, to respect the human rights especially the minorities, to have independent institutions that works in a good way together but are truly independent from government branches as described in the constitution

Albania and other countries of Western Balkans were recognized as potential countries for European Union membership in 2003.Albania was recognized as a potential country for EU membership with other Western Balkan countries in 2003. On 1 April 2009 Stabilization and Association Agreement (SAA) entered into force. Albania submitted its application for membership in October 2013. Albania is participating in the Stabilization and Association process, which provides the legal framework of commitment on some important areas such as are: political, trade and economic issues of the European Union with Western Balkan countries.

As regards to the implementation of the SSA it can be viewed in the light of two main indicators. Firstly, is the approval of the laws that are sanctioned in the National Plan for the implementation of the SAA (2007-2012), partly or fully approximated with the acquis communautaire ${ }^{8}$. Secondly, is the level of their implementation at central and local level. The approval of legislation or placement of institutional mechanisms is in accordance with the time frame defined by the National Plan for the implementation of the SAA, there are noticed many problems related to ban planning of human and financial resources to implement these legal obligations. Even though the Interim Agreement with the EU has been implemented smoothly, problems related to the above mentioned indicators can be noticed. For example the support of the Parliamentary Commission on integration (through which should be filtered every law as regards to the European integration process) without the necessary analytical and consultative capacities and support can't afford with efficiency the aspects of legislative processes. On the other hand, certain initiatives undertaken by the Government of Albania (i.e trading of D2 petrol) are in open conflict with Articles of SAA. The level of the implementation of the SAA is examined by the Annual Progress Report issued by the European Commission, as well as the annual report from an independent group of experts from the civil society (supported by the Open Society Institute of Albania).

\section{Challenges of Achieving EU Candidate Status and the Copenhagen Criteria}

A main challenge Albania faces with regard to the European integration process is the fulfillment of the Copenhagen criteria9 that have been adopted during EU Summit on 21-22 June 1993.

To be part of the European Union a candidate member state should fulfill three important criteria: Political criteria which requires stability of all institutions by guaranteeing the political system that is applied in all Europe the democracy; the rule of law, law is the first and the institutions must respect only the law; also human rights and respect for the other different communities (minorities) that live with the major part of society.

It is important to point out that being a member state of Europe it is needed to have a good neighbors relations and a good regional cooperation too. Also these states that aspire to be member of Europe should respect the international obligations. After political criteria important is and economic criteria which means having a functioning market and being able to build capacity for being competitive with other countries within the European Union.

Albania must show ability to take responsibility of respecting obligation of membership including three areas: political, economic and monetary union. Albania should have real capacity to have an adequate legislation and policies in appropriate to the acquis for having and guaranteeing the sectorial policies, having a functioning justice, independent institutions, security, free and fair elections, an effective staff of administration.

The fulfillment of the three criteria: political, economic and EU standards through the acquis communautaire represents one of the main long-term challenges for Albania. Since the Stabilization and Association process (SAP) was initiated by a decision from the 1999 European Summit in Cologne, Albania shifted into a new phase of relations with the European Union, conditioned upon the above mentioned criteria. Taking into consideration the current progress with

\footnotetext{
${ }^{7}$ Republic of Albania, Ministry of European Integration, National Plan for the Implementation of the SAA (2007-2012), Tirana, September 2007.

${ }^{8}$ Republic of Albania, Ministry of European Integration, National Plan for the Implementation of the SAA (2007-2012), Tirana, September 2007.

${ }^{9}$ Any country seeking membership of the European Union (EU) must conform to the conditions set out by the Article 49 and the principles laid down in Article 6(1) of the Treaty on European Union. Relevant criteria were established by the Copenhagen European Council in 1993 and strengthened by the Madrid European Council in 1995.
} 
regard to the EU integration, Albania faces four main problems: 1) overcoming the political instability in relations between ruling parties and opposition, the creation of trust between parties in order not to aggravate into disability; 2) empowering the public administration by increasing its negotiating capacities and the ability to implement the laws Albania adopts: 3 ) the functioning of powers as sanctioned by the constitution: 4) defining a clear economic model by considering the principle of sustainable development, thus minimizing the informal economy that is mainly supported by remittances from migration and which stimulates apathy, lack of competition; sometimes also acting as a cover to corruption and forms of economic crimes.

The Madrid Summit of the EU in 1995 defines the Madrid criteria related to capacity building of the public administration of the Southeast Europe that aspired EU membership. They compose a very important criterion. Despite hundreds of Euros donated by the EU and other donors for capacity building of the public administration, "public administration syndrome" in Albania is associated with "Albanian election syndrome". After every political rotation civil servants are part of the so-called "spoil system" that damages the quality of the administration. During the long transition period, these movements have been claimed in many civil cases in courts based on unmotivated movement from the working place. As such the capacities of the public administration still remain weak and they should be strengthened through the continuous qualifications and a well-defined career and wage system.

Besides the Parliament of Albania, as sanctioned in the Constitution of the Republic of Albania, civil society sector and the media should serve as a "watch dog", especially to monitor the implementation of national strategies and European integration commitments. This requires a good knowledge on the European integration process, as well as the inclusion of experts in public debates on these issues.

Therefore, it is needed for consulting with civil society organizations and other actors in society to play a role on reforms related to legal and administration. Civil society sector is represented by many small NGOs which are not as much active to influence on the decisions that government takes. In Albania it seems that these NGOs still remain nonfunctional and fragmented. Civil society needs to participate in policy and decision making, but in real remain weak and fragile because they are not well-organized. Albania needs and independent and healthy civil society. A solid civil society is e precondition to a healthy democracy. The presence of an active civil society is in itself a new experience for the society as a whole. Its role in intending to shape the democracy and society can't be denied. A strong and healthy civil society can use its instruments and by products to guarantee stable democracy growth (Tocqueville, 1835). For many years now the "Albanian elections syndrome" is being transformed into a real challenge that is exploiting country's energies. On the other hand, without the fulfillment of the minimal level of democracy- having free and fair elections (Schumpeter, 1950) - the liability of all institutions that depend on the parliament can't be guaranteed. Sometimes a stronger conditional politics from the EU has not been very efficient. The last Freedom House Index shows that Albania still continues to face problems with regard to the fulfillment of the political criteria. The fulfillment of the economic criteria and of the European standards is faced with the obvious obstacles that a developing country like Albania has. Due to the long period of communist regime as well as the long transition period, especially that of 1997, Albania still continues to be faced with poverty, weak road and social infrastructure, lack of control and urban territorial planning, bad management of a natural resources, high poverty rate in rural areas, as well as a non-competitive economic model with the other opened regional markets.

\section{Conclusions}

Albania in tis road towards achieving EU candidate status is mainly faced with political, economic and administrative problems. Firstly, the long political dispute between the Government of Albania and the opposition and the lack of trust in the elected institutions has a negative impact on Albania's image as a consolidated and a functional democracy. Lack of an independent judiciary and a media sector with conflicts of interest of their owners and without the editing independence damages the level of trust of the public related to transparency and accountability. These elements are accompanied by the will to fight organized crime and money laundering indicating the ability to face difficult challenges.

Secondly, the Albanian economy does not represent the model of a competitive economy able to be faced with opened and integrated markets of the EU. The lack of the profiling of the Albanian economy linked with services, tourism and agriculture and based on emigration makes more difficult the strategic aspect of the economic decision-making. For example, from one hand we discuss about tourism in certain areas (i.e Durrës or Vlora) and on the other hand, the investments made in these areas with thermo centrals, petrol processing sites do not meet with the above mentioned 
approach. The concept of sustainable development that lies in the heart of the Treaty ${ }^{10}$ of Lisbon which has entered into force on 1 December 2009, in accordance with its Article 6 represents the economic model of the EU. Meanwhile, Albania's economic model isn't in compliance with this model and sometimes it is in conflict with it. Albania's competitive environment in general, is further complicated by the problems faced with prosperity rights in Albania, the high level of informality, lack of control over the urban territory, as well as a weak quality of the basic infrastructure (water, roads, electricity, sewage, internet etc.)

Thirdly, the lack of adequate administrative capacities at central and local level and the high level of corruption at different levels of governance compose another important challenge and needs a strong political will and concrete steps to be overcome.

Last but not least, Albania needs an independent and healthy civic society. The strengthening of the civic society is a precondition for a healthy democracy. The presence of an active civic society is in itself a new experience for the society as a whole. Its role in intending to shape democracy and our society cannot be denied. A strong and healthy civic society can use its instruments and byproducts to guarantee stable democracy growth. Even though the civic society is not and should not, be part of politics it does not mean that it should be indifferent to politics that touch our daily lives. Previous experiences of the Western countries with consolidated democracies have shown that civic societies can have the power and the capability to properly cover and evaluate a countries government branches. It is imperative that despite various opinions on various issues the people should consciously agree and adhere to certain cultural and political values and that they should hold any government from any part of the political specter to respect and go by these values. Without this set of common values, the civic society is dead. At present, the civic society is week and inefficient as it is in many cases an extension of various political parties. It reflects the political polarization it serves. These close ties with politics damages its function and its mission as the independent observing eye, serving only the common good, which it should be. If this behavior continues, the civic society will simply transform into a divided militant base.

There are other challenges worthy of mentioning but, I believe that the three stated above are the most important ones. In conclusion, the road that leads to a sound democracy and European Integration is a very hard and complicate road. One that l'm confident we can master. Time has shown us that the dream of building a stable democracy can be achieved if we realize our responsibilities. As we steadily embrace democratic principles and turn them into parts of our culture, we pave our way towards the European family. The integration process cannot be successful without the constructive involvement of all actors in our society. A democratic system can't be successful without democratic parties, political elites equipped with democratic culture, without independent institutions and a self-conscious civic society who takes part and reacts to cultural and system shaping phenomena. Democracy is not means but our common desired end. Also the role of European Union is the most important. We need European Union because it is like a mother that helps her child. So, we can develop our democratic values only if we are supported by the members of EU. We need from their previous experience, we need their control and we need their monitoring. If there are next to us only in this way we can implement the democratic values. We can't develop democratic values because we have lack of democratic experience, lack of democratic values. As a conclusion if we want to go into the Europe we need more and more observing eyes, we need more helping of member states of EU member states.

\section{References}

Dahl, R. (1989) Democracy and Its Critic, New Haven, CT: Yale University Press.

Dahl, R. (2005) POLIARKIA, (Poliarchy), Tiranë: PEGI.

Delsol, M (2000) Mendimi Politik në Shekullin e XX, (Political Thought in the Twentieth Century), Tiranë: Onufri

Durham, Edith, M., (1905), The burden of the Balkan, London: Nelson

Epler, E (2001) Rikthimi i politikës, (Return Policy), Tiranë: ISPS \& Rinia.

Giddens, Anthony, (1984), The Constitution of Society. Cambridge: Polity

Huntington, S. (1991) The Third Wave: Democratization in the Late Twentieth Century, Norman: University of Oklahoma Press.

Inglehart, R. (1990) The Renaissance of Political Culture, Princenton-New Jersey: Princenton University Press.

Mayer, L. (2003) POLITIKAT KRAHASUESE, (Comparative Politics), Tiranë: ORA.

Mc Lean, I. (2001) Oxford Fjalor Politik, (Political Dictionary) Tiranë: Shtëpia e Librit dhe e Komunikimit.

Moore, B. (1966) The Social Origins of Democracy and Dictatorship, Boston: The Beacon Press.

Ngjela, S. (2006) Reformë Shqiptare, (Albanian Reform), Tiranë: Shtypshkronja MNS.

Pauell, K. (1999) Udhëtimi im Amerikan, (My American Journey), Tiranë: Shtëpia Botuese e Ushtrisë

Sartori, G. (2006) Edhe një herë për teorinë e Demokracisë, (Agaian for Democracy Theory), Tiranë: DITURIA.

10 Official Journal of the European UNION, 17.12.2007, Treaty of Lisbon, Amending the Treaty on European Union and the Treaty establishing the European Community (2007/C 306/01). 
Schumpeter, J. (1950) Capitalism, Socialism and Democracy, New York: Harper and Row Torchbooks.

Schumpeter, J. (1924) Modern Democracies, New York: Macmillan.

Tokëvill, A. (2002) Demokracia në Amerikë, (Democracy in America), Tiranë: Fondacioni Soros \& Kristalina-KH.

Vajdenfeld, V. (1999) Demokracia dhe Ekonomia e Tregut në Europën Lindore, (Democracy and Market Economy in the Eastern Europe), Tiranë: Shtëpia e Librit dhe Fondacioni Soros.

Zeneli, B. (2009) POLITIKANET E REJA, Sistemi politik demokratik dhe gjinia, (The New Politicians, Democratic political system and gender), Tiranë: TOENA.

COM (2003) 139 Final

COM (2009) 533

Commission of the European Communities, Brussels, 14 October 2009, SEC (2009) 1337

Council decision 2008/210/ EC

Council of the European Union, Brussels, 22 May 2006

Republic of Albania, Ministry of European Integration, National Plan for the Implementation of the SAA (2007-2012), Tirana, September 2007.

Treaty of Amsterdam on 1 May 1999

Treaty of Lisbon, Amending the Treaty on European Union and the Treaty establishing the European Community (2007/C 306/01).ffairs Council Conclusions, 29-30 April 1997 